Dermatology 2008;217:380

DOI: $\underline{10.1159 / 000162180}$

\section{Alopecia Areata Universalis during Treatment of Rheumatoid Arthritis with Anti-TNF- $\alpha$ Antibody (Adalimumab)}

\author{
Y. Chaves a, G. Duarte ${ }^{\mathrm{a}}$, B. Ben-Said ${ }^{\mathrm{a}}$, J. Tebib ${ }^{\mathrm{b}}$, F. Berard ${ }^{\mathrm{a}}$,
} J.F. Nicolas ${ }^{a}$

${ }^{a}$ UF Allergology and Clinical Immunology and ${ }^{b}$ Department of Rheumatology, CH Lyon-Sud, UFR Lyon-Sud, University Lyon 1, Lyon, France

Key Words

Alopecia areata $\cdot$ Anti-TNF

We read with great interest the articles of Fabre and Dereure on 'Worsening alopecia areata and de novo occurrence of multiple halo nevi in a patient receiving infliximab' [1] and of Pelivani et al. on 'Alopecia areata universalis elicited during treatment with adalimumab' [2], and we want here to report on a similar observation of a rapidly progressive alopecia areata (AA) during treatment with adalimumab for rheumatoid arthritis (RA).

\section{Case Report}

A 38-year-old woman with RA from the age of 15 years had been treated with adalimumab and methotrexate for 1 year and then with adalimumab alone for another year, with an excellent control of RA. She suddenly developed a rapid course of extensive hair loss resulting within 3 months in a typical form of AA universalis. There was no evident triggering factor (infection, stress or trauma), and she had no personal or familial history of AA. There were no other complaints, and the clinical examination was normal. The decision to stop adalimumab was made after consulting her rheumatologist.

\section{Comments}

AA is a nonscarring autoimmune hair loss condition frequently recurrent and resistant to treatment [3]. Although its pathophysiology remains unknown, it is postulated that CD4+ and CD8+ T cells reactive to hair bulb autoantigens induce the inflammatory process leading to hair loss $[3,4]$. In this respect, AA is frequently associated with other autoimmune diseases such as insulin-dependent diabetes, RA, vitiligo or Hashimoto's disease. The present observation together with that of Pelivani et al. [2] suggests that adalimumab could trigger AA in predisposed individuals. The rapid development of AA in our patient may also be related to the interruption of methotrexate, an effective treatment of AA [5], which was associated with adalimumab for 1 year prior to the onset of the disease.

The role of TNF- $\alpha$ in the pathophysiology of autoimmunity, and more specifically of AA, appears complex. On the one hand, TNF- $\alpha$ was considered an important cytokine involved in the hair loss, the more so because it inhibits hair growth in vitro and TNF- $\alpha$-producing cells can be found in the mononuclear infiltrate surrounding the hair follicle [2]. However, this hypothesis was ruled out by a clinical trial which showed no efficacy of etanercept in the treatment of AA [6]. On the other hand, TNF- $\alpha$ appears to protect from hair loss since the blockade of TNF- $\alpha$-mediated effects by monoclonal antibodies resulted in the worsening of AA with infliximab in 1 patient [1], the recurrence of AA in a patient treated with infliximab and adalimumab [cited in 2] and in the induction of AA in Pelivani's [2] and our present observations.

That TNF- $\alpha$ blockers promote autoimmunity is known from both experimental and clinical studies [6]. In this respect, adalimumab, like other anti-TNF- $\alpha$ monoclonal antibodies, has been associated with the induction or aggravation of autoimmune diseases such as systemic lupus erythematosus and lupus-like syndrome [7]. Positive antinuclear antibody titers have been detected in patients treated with adalimumab and other anti-TNF- $\alpha$ therapies. Recent fundamental studies have shown that TNF- $\alpha$ promotes both the expansion and suppressive functions of CD4+ regulatory $\mathrm{T}$ cells which play an essential role in maintaining immune tolerance and preventing autoimmunity [8]. Therefore it is possible that anti-TNF- $\alpha$-induced autoimmunity is mediated by the inhibition of the suppressive functions of regulatory T cells [9].

\section{References}

1 Fabre C, Dereure O: Worsening alopecia areata and de novo occurrence of multiple halo nevi in a patient receiving infliximab. Dermatology 2008;216:185-186.

-2 Pelivani N, Hassan AS, Braathen LR, Hunger RE, Yawalkar N: Alopecia areata universalis elicited during treatment with adalimumab. Dermatology 2008;216:320-323.

-3 Alexis FA, Dudda-Subranya R, Sinha AA, et al: Alopecia areata: autoimmune basis of hair loss. Eur J Dermatol 2004;14:364-370.

4 Hequet O, Vocanson M, Saint-Mézard P, Kaiserlian D, Nicolas JF, Bérard F: CD4+ T cells prevent skin autoimmunity during chronic autologous graft-versus-host disease. Am J Transplant 2004;4:872-878.

5 Joly P: The use of methotrexate alone or in combination with low doses of oral corticosteroids in the treatment of alopecia totalis or universalis. J Am Acad Dermatol 2006;55:632-636.

-6 Strober BE, Siu K, Alexis AF, Kim G, Washenik K, Sinha A, Shupack JL: Etanercept does not effectively treat moderate to severe alopecia areata: an open-label study. J Am Acad Dermatol 2005;52:159-163.

7 Kollias G: TNF pathophysiology in murine models of chronic inflammation and autoimmunity. Semin Arthritis Rheum 2005;34(suppl 1): 3-6.

8 De Bandt M, Sibilia J, Le Loët X, Prouzeau S, Fautrel B, Marcelli C, Boucquillard E, Siame JL, Mariette X, Club Rhumatismes et Inflammation: Systemic lupus erythematosus induced by anti-tumour necrosis factor alpha therapy: a French national survey. Arthritis Res Ther 2005; 7:R545-R551.

-9 Chen X, Bäumel M, Männel DN, Howard OM, Oppenheim JJ: Interaction of TNF with TNF receptor type 2 promotes expansion and function of mouse CD4+CD25+ T regulatory cells. J Immunol 2007;179:154-161.

\section{J.F. Nicolas}

University Lyon 1, UFR Lyon-Sud

Allergology and Clinical Immunology, CH Lyon-Sud

FR-69495 Pierre-Benite Cedex (France)

Tel. +33 478861 570, Fax +33478 861528

E-Mail jean-francois.nicolas@chu-lyon.fr

\section{KARGER}

(c) 2008 S. Karger AG, Basel

Fax +41613061234 E-Mail karger@karger.ch www.karger.com 